https://doi.org/10.52058/2708-7530-2021-11(17)-270-280

Копчак Юрій Степанович кандидат економічних наук, доцент кафедри менеджменту і маркетингу, Прикарпатський національний університет імені Василя Стефаника, вул. Шевченка, 57, м. Івано-Франківськ, 76018, тел.: (096) 80691-36, e-mail: yurii.kopchak@ @ pu.edu.ua,https://orcid.org/0000-0002-0560-4204

Васюк Інна Володимирівна кандидат економічних наук, завідувач кафедри обліку і фінансів, Відокремлений структурний підрозділ закладу вищої освіти «Відкритий міжнародний університет розвитку людини «Україна» Дубенська філія, вул. Шевченка, 14, м. Дубно, 35600, тел.: (066) 405-04-83, e-mail: inesaha2@gmail.com, https://orcid.org/0000-0003-3342-6633

Григорук Анатолій Ананійович кандидат економічних наук, доцент, доцент кафедри філософії та суспільних наук, Тернопільський національний педагогічний університет імені Володимира Гнатюка, вул. М. Кривоноса, 2, м. Тернопіль, 46027, тел.: (067) 960-38-88, e-mail: a.hryhoruk@ukr.net, https://orcid.org/0000-0003-4200-4440

\title{
МАРКЕТИНГ ТЕРИТОРІЙ ЯК ІНСТРУМЕНТ ЕФЕКТИВНОСТІ ФУНКЦІОНУВАННЯ РЕГІОНУ
}

Анотація. Одним 3 інструментів ефективного управління соціальноекономічним розвитком територій, у тому числі розвитком регіонів, $\epsilon$ маркетинг територій. Основне завдання маркетингу територій полягає у забезпеченні привабливості території не лише для суб'єктів, що здійснюватимуть зовнішнє інвестування, але і для того, щоб підвищити рівень комфортності проживання населення в цій території. Маркетинг територій треба розуміти як відповідний управлінський інструмент, застосування якого спрямоване на формування позитивного іміджу територій і регіону зокрема, підвищення зацікавленості наявних та потенційних інвесторів до економічної діяльності територій та регіону зокрема, а також створення сприятливого середовища, в якому будуть всі належні умови для досягнення високого рівня $\mathrm{i}$ якості життя населення. Стратегія маркетингу територій у контексті підвищення ефективності функціонування регіону передбачає ряд цілей, досягнення яких вимагає проведення спеціальних маркетингових заходів. У статті проведено аналіз ефективності функціонування регіону 3 позиції залучення інвестицій у ці процеси, так як інвестиції - це один із маркетингових напрямків. Для аналізу взято динаміку залишків залучених прямих інвестицій у розвиток України та трьох регіонів, тобто ІваноФранківської, Рівненської та Тернопільської областей. В результаті аналізу 
встановлено, що найменше 3-поміж досліджуваних регіонів інвестиції з-за кордону одержує Тернопільська область, дещо вищими, але не на багато, є надходження прямих інвестицій у Рівненську та Івано-Франківську області. На прикладі результатів, отриманих за підсумками аналізу, встановлено, що на сьогодні не до кінця зреалізованими $\epsilon$ напрямки маркетингу, зокрема інвестиційний напрямок, що пояснюється нестабільною динамікою залучення інвестицій у розвиток регіонів.

Ключові слова: маркетинг територій, регіон, маркетингові інструменти, стратегія розвитку, ефективність, інвестиції.

Kopchak Yuriy Stepanovych Candidate of Economic Sciences, Associate Professor of the Department of Management and Marketing, Vasyl Stefanyk Precarpathian National University, Shevchenko St., 57, Ivano-Frankivsk, 76018, tel.: (096) 806-91-36, e-mail: yurii.kopchak@pnu.edu.ua, https://orcid.org/00000002-0560-4204

Vasiuk Inna Volodymyrivna Candidate of Economic Sciences, Head of the Department of Accounting and Finance, Separate structural subdivision of the institution of higher education "Open International University of Human Development "Ukraine" Dubna branch, Shevchenko St., 14, Dubno, 35600, tel.: (066) 405-04-83, e-mail: inesaha2@gmail.com, https://orcid.org/0000-0003-3342-6633

Hryhoruk Anatoliy Ananiyovych Candidate of Economic Sciences, Associate Professor, Associate Professor the Department of Philosophy and Social Sciences, Ternopil Volodymyr Hnatiuk National Pedagogical University, M. Kryvonosa St., 2, Ternopil, 46027, tel.: (067) 960-38-88, e-mail: a.hryhoruk@ukr.net, https://orcid.org/0000-0003-4200-4440

\title{
TERRITORY MARKETING AS A TOOL OF EFFICIENCY OF REGIONAL FUNCTIONING
}

\begin{abstract}
One of the tools for effective management of socio-economic development of territories, including the development of regions, is the marketing of territories. The main task of marketing territories is to ensure the attractiveness of the territory not only for entities that will make foreign investment, but also to increase the level of comfort of the population in this area. Territorial marketing should be understood as an appropriate management tool, the application of which is aimed at forming a positive image of territories and regions in particular, increasing the interest of existing and potential investors in economic activities of territories and region in particular, and creating a favorable environment. level and quality of life of the population. The strategy of marketing territories in the context of improving the efficiency of the region provides a number of goals, the achievement
\end{abstract}


of which requires special marketing activities. The article analyzes the effectiveness of the region from the standpoint of attracting investment in these processes, as investment is one of the marketing areas. The dynamics of the balances of attracted direct investments in the development of Ukraine and three regions, ie IvanoFrankivsk, Rivne and Ternopil regions, is taken for analysis. As a result of the analysis it was found that the least among the studied regions investments from abroad are received by Ternopil region, slightly higher, but not by much, is the inflow of direct investments in Rivne and Ivano-Frankivsk regions. On the example of the results obtained as a result of the analysis, it is established that the marketing directions, in particular the investment direction, are not fully realized today, which is explained by the unstable dynamics of attracting investments in the development of regions.

Keywords: marketing of territories, region, marketing tools, development strategy, efficiency, investments.

Постановка проблеми. Підвищення конкурентоспроможності розвитку регіону відбувається на базі ефективного оволодіння та ефективного використання територіями потенціалу, що $є$ у їх власності. Окрім того, для підвищення конкурентоспроможності розвитку регіону доцільно також ефективно використовувати конкурентні переваги регіону, посилювати територіальну соціально-економічну інтеграцію і досягати належної рівноваги у просторовому розвитку, зокрема завдяки дієвому державному i регіональному управлінні та постійному розробленні та впровадженні інноваційних проектів як органами державної влади, так і органами місцевого самоврядування.

Практика показує, що одним 3 інструментів ефективного управління соціально-економічним розвитком територій, у тому числі розвитком регіонів, $\epsilon$ маркетинг територій. Завдяки маркетингу територій створюється належна економіко-аналітична база для здійснення управлінського впливу 3 ціллю досягнення ефективного розвитку держави i iï регіонів у контексті набуття ними значних конкурентних переваг.

Аналіз останніх досліджень і публікацій. Великий вклад у розвиток теоретико-методологічних та практичних аспектів розроблення та впровадження маркетингу в управління територіями здійснили такі науковці та дослідники як О. Дудкіна, Д Лук'яненко, Н. Назаров, С. Мартова, О. Панкрухін, С. Смерічевський, А. Старостіна, Т. Стройко та інші.

Здійснені науковцями дослідження формують значний теоретикометодологічний базис для того, щоб забезпечити ефективне впровадження маркетингу територій у систему забезпечення ефективного функціонування розвитку регіону. Однак, не до кінця розкритими залишаються такі питання 3 позиції практичного підходу. 
Метою статті $\epsilon$ розкриття концептуальних засад розроблення та впровадження маркетингу територій у систему забезпечення ефективності функціонування регіону.

Виклад основного матеріалу. Основне завдання маркетингу територій полягає у забезпеченні привабливості території не лише для суб'єктів, що здійснюватимуть зовнішнє інвестування, але і для того, щоб підвищити рівень комфортності проживання населення в цій території, зокрема мається на увазі: 1) підвищення рівня якості життя населення цієї території; 2) формування позитивного іміджу території перед інвесторами та підвищення рівня іiі престижності; 3) підвищення рівня інвестиційної привабливості; 4) підвищення рівня конкурентоспроможності території та конкурентоспроможності виробництва, що здійснюється у цій місцевості; 5) підвищення рівня споживацьких якостей товарів та послуг, що виробляються на цій території, зокрема за рахунок підвищення рівня якості та створення нових конкурентних властивостей.

Акцентуючи увагу на споживачах продукції та послуг, що пропонуються територією, свого часу Ф. Котлером [1] виділено чотири типи споживачів території, як мають інтерес до таких товарів та послуг. Так, цими споживачами є: відвідувачі, тобто ті особи, які приїжджали у відрядження чи з ціллю участі у конференціях та/або переговорах; населення, що проживає на цій території; представники бізнесу; суб'єкти, що здійснюють діяльність на експортних ринках.

Виходячи 3 інформації, представленої у [2], у контекст управління соціально-економічним розвитком регіону закладено орієнтацію на такі традиційні підходи до маркетингу територій як інструменту забезпечення ефективності функціонування цього регіону, як:

- підхід вибору способу розширення економічної діяльності в регіоні та нарощення потенціалу цього регіону, зокрема у напрямку підвищення потенціалу виробництва продукції;

- підхід вибору виду диверсифікації економіки регіону у відповідному напрямку та оптимізації структури видів економічної діяльності в регіоні;

- підхід до розроблення та впровадження управлінського механізму, що буде націлений на забезпечення раціонального довгострокового управління розвитком території, формування бренду території у контексті підвищення конкурентних переваг, просування на нові ринки продукції, що виробляється в регіоні, пристосування до неочікуваних кон'юнктурних коливань та впливу факторів зовнішнього середовища.

Врахування зазначених вище концептуальних підходів дозволяє представити маркетинг територій як відповідний управлінський інструмент, застосування якого спрямоване на формування позитивного іміджу територій і регіону зокрема, підвищення зацікавленості наявних та потенційних інвесторів до економічної діяльності територій та регіону зокрема, а також на створення 
сприятливого середовища, в якому будуть всі належні умови для досягнення високого рівня і якості життя населення. Маркетинг територій, будучи інструментом ефективності функціонування регіону, також повинен виконувати функцію максимізації задоволення споживчих потреб у продукції регіону у контексті встановлення i підтримання на належному рівні конкурентних переваг регіону.

Що стосується розвитку безпосередньо територій, то маркетинг територій як інструмент підвищення ефективності територій, має включати комплекс маркетингових технологій, а також базуватись на положеннях стратегії розвитку територій. 3 огляду на те, маркетинг територій має гуртуватись на наявних перевагах території, у тому числі на ресурсах, а вже потім враховувати потреби територій. Варто зауважити, що задоволення потреб не може відбутись, якщо вони не становлять основу розвитку територій [3, с. 37].

Одними із ключових напрямків маркетингу територій є: 1) залучення інвестицій у розвиток цих територій; 2) відкриття нових видів діяльності; 3) підвищення престижності та іміджу.

Однак досягнення вищезазначених напрямків певним чином створює негативні наслідки для навколишнього середовища територій (до прикладу, виникають нові види діяльності, але вони породжують значну шкоду навколишньому середовищу). Серед інших негативних наслідків треба відзначити: 1) виснаження природних ресурсів, що задіяні у виробництві і не тільки; 2) у багатьох випадках закриття видів діяльності, тобто закриття бізнесу; 3) низька ідентичність та самобутність громад територій.

3 огляду на те, треба наголосити, що проведення маркетингових заходів ні в якому разі не має виключно проводитись органами місцевого самоврядування. Участь у розробленні маркетингової політики повинна насамперед брати громада, а не деякі зацікавлені у цьому групи осіб. Пріоритети майбутнього розвитку територій мають стати безпосередньо рівновагою між заходами для цього органів місцевого самоврядування та представників приватного бізнесу. Саме завдяки злагодженій та сприятливій взаємодії органів місцевого самоврядування та представників бізнесу можна не тільки забезпечити розвиток окремої території, але і регіону в цілому.

Проте взаємодія органів місцевого самоврядування та представників бізнесу має базувати на формальних засадах та бути реальною. 3 огляду на те, у джерелі [4] запропоновано включати у процес розвитку територій участь громадян. Так, участь громадян в процесах ухвалення рішень стосовно розвитку територій, на думку науковця, на сьогодні представлена такими видами, як відсутність участі громадян у розвитку територій, видимість участі громадян у розвитку територій або участь громади у розвитку територій, влада якої у такому процесі є найбільш визначальною. 
Що стосується першого виду участі у розвитку територій, то тут відсутній прямий вплив громадян на розвиток територій, а саме залучення $\epsilon$ більше формальним процесом i на практиці не виражає безпосередньої участі громадян у таких процесах, але вимагає підтримки громадян. Акцентуючи увагу на другому виді участі громадян у розвитку територій, то такий вид характеризується інформування громадян, їх консультуванням. У такому випадку громадяни $\epsilon$ «видимі» у розвитку територій. Водночас участь громадян у розвитку регіону, за якою передбачено владу громадян у таких процесах, свідчить про те, громадяни здійснюють суттєвий вплив на вирішення проблемних питань та досягнення пріоритетів розвитку регіону. У такій ситуації громадяни $є$ повноправними партнерами держави у напрямку забезпечення розвитку регіону.

У розвитку територіальних громад є зацікавленою досить велика кількість осіб. Це органи державної влади, органи місцевого самоврядування, представники бізнесу, фінансові установи, неурядові громадські організації, споживачі продукції, навчальні установи та заклади [5, с. 34].

Дещо іншу класифікацію зацікавлених осіб у розвитку територій наводить А. Панкрухін [6]. Так науковець зауважує, що доцільно виділяти шість учасників, що є зацікавленими особами у розвитку територій. Такими особами $\epsilon$ ініціатори; особи, які здійснюють безпосередній вплив на процеси розвитку; особи, які приймають рішення; особи, які ухвалюють рішення; споживачі продукції, що виробляється в регіоні; особи, що реалізують ухвалене рішення.

Маркетинг територій як інструмент забезпечення ефективності функціонування регіону має базуватись на впровадженні у практику таких ключових елементів як продукція регіону, цінова політика на ресурси регіону, збутова політика і маркетингові комунікації.

Стратегія маркетингу територій у контексті підвищення ефективності функціонування регіону передбачає ряд цілей, досягнення яких вимагає проведення спеціальних маркетингових заходів (рис. 1). 


\section{СТРАТЕГІЯ МАРКЕТИНГУ ТЕРИТОРІЙ: підвищення ефективності функціонування реzіону}

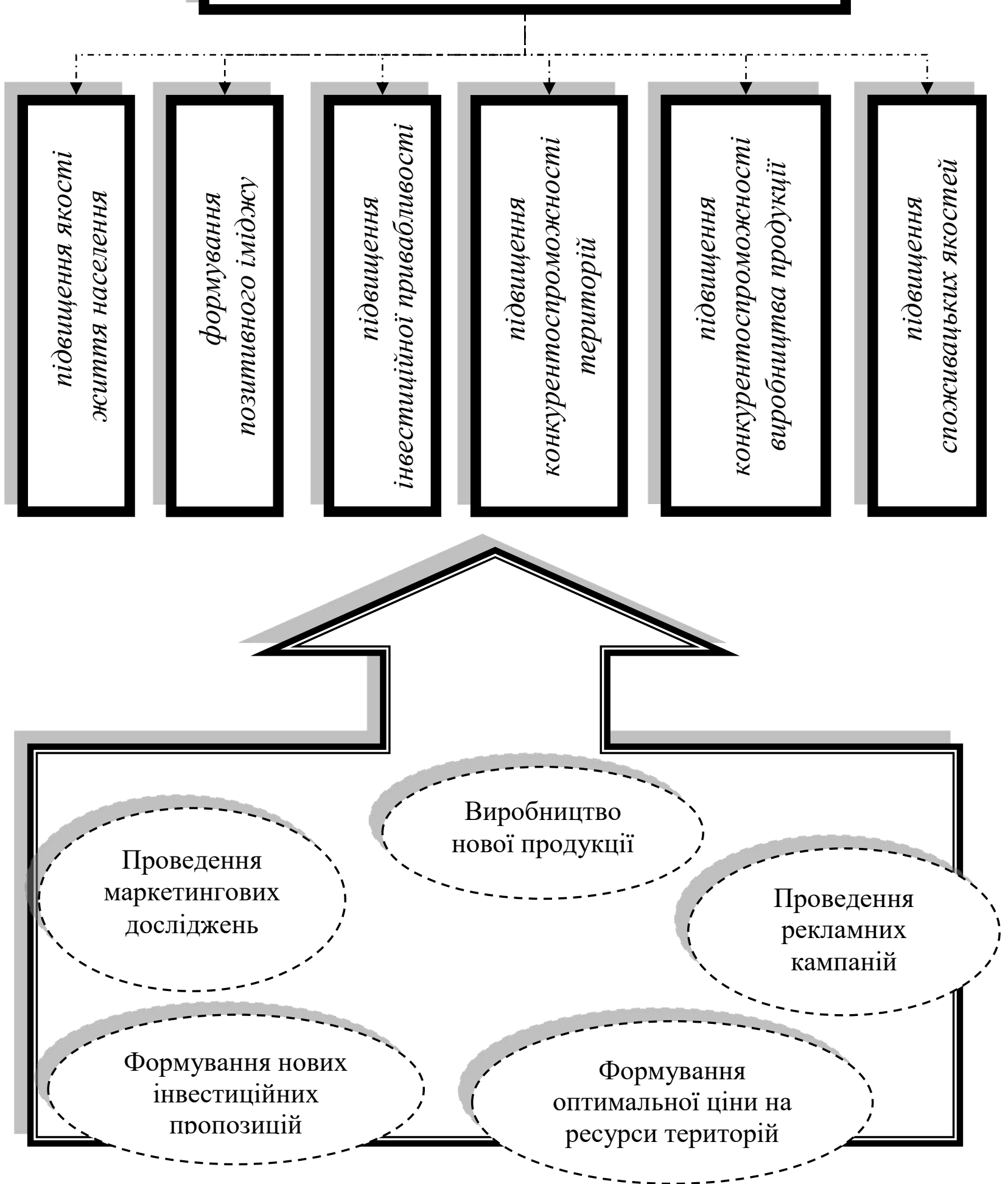

Pис. 1. Особливості стратегії маркетингу територій в контексті забезпечення ефективного функиіонування регіону

Джерело: розроблено авторами на основі проведених досліджень 
У контексті розкриття мети дослідження доцільно здійснити аналіз ефективності функціонування регіону 3 позиції залучення інвестицій у ці процеси, так як інвестиції - це один із маркетингових напрямків.

Для аналізу взято динаміку залишків залучених прямих інвестицій у розвиток України та трьох регіонів, тобто Івано-Франківської, Рівненської та Тернопільської областей (табл. 1).

Таблиия 1

Динаміка залишків залучених прямих інвестицій у розвиток України та регіонів

\begin{tabular}{|c|c|c|c|c|c|c|c|c|c|c|c|c|}
\hline \multirow[b]{2}{*}{ Регіон } & \multicolumn{2}{|c|}{$\begin{array}{c}\mathrm{Ha} \\
31.12 .2015 \\
\end{array}$} & \multicolumn{2}{|c|}{$\begin{array}{c}\mathrm{Ha} \\
31.12 .2016 \\
\end{array}$} & \multicolumn{2}{|c|}{$\begin{array}{c}\mathrm{Ha} \\
31.12 .2017 \\
\end{array}$} & \multicolumn{2}{|c|}{$\begin{array}{c}\mathrm{Ha} \\
31.12 .2018 \\
\end{array}$} & \multicolumn{2}{|c|}{$\begin{array}{c}\mathrm{Ha} \\
31.12 .2019 \\
\end{array}$} & \multicolumn{2}{|c|}{$\begin{array}{c}\mathrm{Ha} \\
31.12 .2020 \\
\end{array}$} \\
\hline & $\begin{array}{c}\text { млн. } \\
\text { дол. } \\
\text { СШ } \\
\text { А }\end{array}$ & $\%$ & $\begin{array}{c}\text { млн. } \\
\text { дол. } \\
\text { СШ } \\
\text { А }\end{array}$ & $\%$ & $\begin{array}{c}\text { млн. } \\
\text { дол. } \\
\text { СШ } \\
\text { А }\end{array}$ & $\%$ & $\begin{array}{c}\text { млн. } \\
\text { дол. } \\
\text { СШ } \\
\text { А }\end{array}$ & $\%$ & $\begin{array}{c}\text { млн. } \\
\text { дол. } \\
\text { СШ } \\
\text { А }\end{array}$ & $\%$ & $\begin{array}{c}\text { млн. } \\
\text { дол. } \\
\text { СШ } \\
\text { А }\end{array}$ & $\%$ \\
\hline Україна & 43780,3 & 100,0 & 45195,3 & 100,0 & 45179,2 & 100,0 & 44008,8 & 100,0 & 51386,6 & 100,0 & 49686,5 & 100,0 \\
\hline $\begin{array}{l}\text { Івано- } \\
\text { Франківська } \\
\text { область }\end{array}$ & 712,5 & 1,6 & 718,5 & 1,6 & 848,0 & 1,9 & 737,6 & 1,7 & 512,1 & 1,0 & 679,4 & 1,4 \\
\hline $\begin{array}{l}\text { Рівненська } \\
\text { область }\end{array}$ & 298,7 & 0,7 & 273,1 & 0,6 & 260,0 & 0,6 & 237,3 & 0,5 & 305,2 & 0,6 & 374,7 & 0,8 \\
\hline $\begin{array}{l}\text { Тернопільська } \\
\text { область }\end{array}$ & 213,5 & 0,5 & 77,0 & 0,2 & 71,6 & 0,2 & 121,3 & 0,3 & 209,6 & 0,4 & 225,1 & 0,5 \\
\hline
\end{tabular}

Джерело: сформовано на основі [7].

В результаті аналізу видно, що найменше 3-поміж досліджуваних регіонів інвестиції з-за кордону одержує Тернопільська область (частка інвестицій у цю область становить 0,2-0,5 \% від загальної кількості прямих інвестицій в Україну. Дещо вищими, але не на багато, надходять прямі інвестиції у Рівненську область. Так, питома вага прямих інвестицій, що надходять у цей регіон коливається в межах 0,5-0,8 \% від загальноукраїнського показника. За аналізований період прямі інвестиції у Івано-Франківську область $\epsilon$ найбільшими, однак частка цих інвестицій в середньому коливається в межах 1,0-1,9 \% від загальноукраїнського показника.

Акцентуючи увагу на темпах приросту прямих інвестицій у розвиток України та досліджуваних регіонів, слід зауважити, що найбільш нестабільна динаміка у прирості залишків прямих інвестицій спостерігалася у Тернопільській області. Так, після падіння у 2017 році на 7,01\%, обсяг залишків прямих інвестицій у 2018-2020 років суттєво зростав (рис. 2). У 2020 році проти 2016 року обсяг залишків прямих інвестицій збільшився на 192,34 \%. 


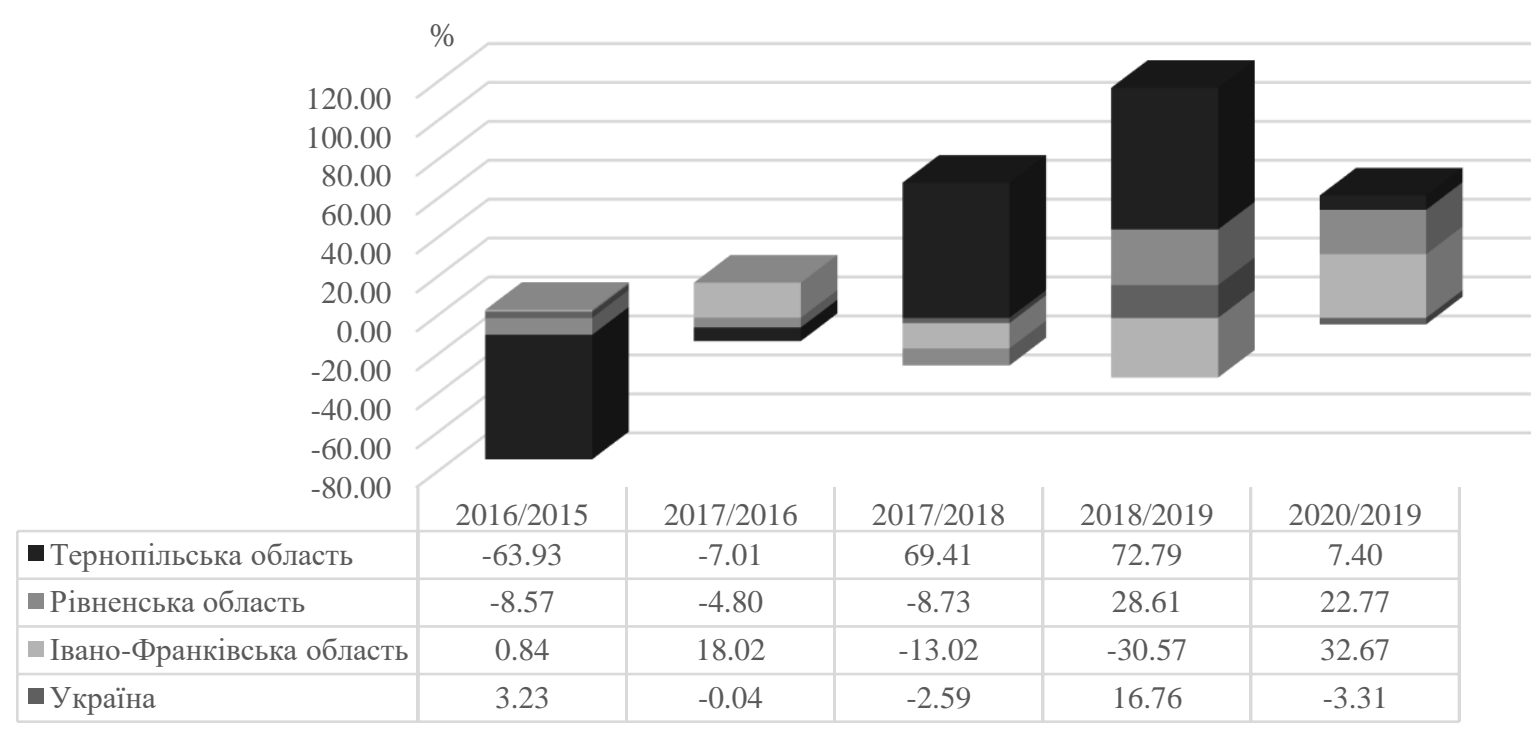

Рис. 2. Темпи приросту залишків прямих інвестицій в Украйну та регіони Джерело: сформовано авторами на основі [7].

На відміну від Тернопільської області, у Рівненській області після тенденційного падіння у 2017 році обсяг залишків прямих інвестицій у 2020 році проти цього року збільшився на 44,12 \%. Натомість у Івано-Франківській області обсяг залишків прямих інвестицій тенденційно скорочувався із 2018 року. Так, у 2020 році проти 2018 року скорочення становило 19,88 \%. По Україні також відбулась нестабільна динаміка обсягу залишків прямих інвестицій. Після тенденційного падіння протягом 2017-2018 років обсяг залишків прямих інвестицій у 2019 році зріс, а у 2020 році знову скоротився на $3,31 \%$.

Таким чином, на прикладі результатів, отриманих за підсумками аналізу, треба констатувати, що на сьогодні не до кінця зреалізованими $є$ напрямки маркетингу, зокрема інвестиційний напрямок. Це пояснюється нестабільною динамікою залучення інвестицій у розвиток регіонів.

Висновки. За результатами здійсненого дослідження установлено, що маркетинг територій виступає ключовим інструментом підвищення ефективності функціонування регіону та забезпечення конкурентоспроможності цього регіону. Маркетинг територій як інструмент сприяє ефективному донесенню інформації щодо розвитку регіону зовнішнім споживачам, тобто інвесторам, підприємцям, громадянам, що проживають у цьому регіоні, громадським інституціям, суб'єктам ринкової інфраструктури. Маркетинг територій впливає на просування цих територій у систему функціонування інвестиційних ресурсів, а також забезпечує формування стратегії та ряду програм, якими передбачено цілі та напрями розвитку регіону. Через маркетинг територій відбувається стимулювання операцій 3 продажу продукції, що виробляється в регіоні, а також формування позитивного іміджу у контексті забезпечення конкурентних переваг регіону у недалекій перспективі. 
Основною метою маркетингу території $\epsilon$ обгрунтування комплексу методів щодо того, як підвищити привабливість регіону у напрямку виробництва конкурентоспроможної продукції.

\section{Лimepamypa:}

1. Котлер Ф. Маркетинг мест. Привлечение инвестиций, предприятий, жителей и туристов в города, коммуны, регионы и страны Европы. СПб.: Стокгольмская школа экономики в Санкт-Петербурге, 2005. 382 с.

2. Дудкіна О. Маркетинг територій як інструмент забезпечення конкурентоспроможного розвитку. Регіональні аспекти розвитку продуктивних сил України. 2016. № 21. С. 9-13.

3. Ільченко Н.В., Григор М.К. Маркетинг громади - засіб економічного розвитку громади. Збірник матеріалів X Міжнародної конференції «Теорія і практика сучасної економіки». Черкаси : ЧДТУ, 2009. Т. 2. С.37-39.

4. Ільченко Н.В. Концепція участі та методи залучення населення до розвитку територіальної громади. Державне управління : удосконалення та розвиток. 2010 . №7. http://www.dy.nayka.com.ua.

5. Сачук Т.В. Териториальний маркетинг. СПб. : Питер, 2009. 368 с.

6. Панкрухин А.П. Маркетинг территорий http:// www.marketologi.ru/books/mterr.html.

7. Національний банк України. Залишки за інструментами прямих інвестицій за регіонами, країнами світу та видами економічної діяльності. https://bank.gov.ua/ua/statistic/ sector-external/data-sector-external\#1

\section{References:}

9. Kotler F. (2005). Marketing mest. Privlechenie investitsiy, predpriyatiy, zhiteley i turistov v goroda, kommuny, regiony i strany Yevropy [Attraction of investments, enterprises, residents and tourists in cities, communes, regions and countries of Europe]. SPb: Stokgolmskaya shkola ekonomiki $v$ Sankt-Peterburge - SPb .: Stockholm School of Economics in St. Petersburg, 382 [in English].

10. Dudkina O. (2016). Marketyngh terytorij jak instrument zabezpechennja konkurentospromozhnogho rozvytku [Marketing of territories as a tool to ensure competitive development]. Reghionaljni aspekty rozvytku produktyvnykh syl Ukrajiny - Regional aspects of development of productive forces of Ukraine, 21, 9-13 [in Ukrainian].

11. Iljchenko N.V., Ghryghor M.K. (2009). Marketyngh ghromady - zasib ekonomichnogho rozvytku ghromady [Community marketing - a means of economic development of the community]. Zbirnyk materialiv Kh Mizhnarodnoji konferenciji "Teorija i praktyka suchasnoji ekonomiky" - Proceedings of the X International Conference "Theory and Practice of Modern Economics", 2, 37-39 [in Ukrainian].

12. Iljchenko N.V. (2010). Koncepcija uchasti ta metody zaluchennja naselennja do rozvytku terytorialjnoji ghromady [The concept of participation and methods of involving the population in the development of the territorial community]. Derzhavne upravlinnja: udoskonalennja ta rozvytok - Public administration: improvement and development, 7. www.dy.nayka.com.ua. Retrieved from http://www.dy.nayka.com.ua [in Ukrainian].

13. Sachuk T.V. (2009). Terytoryaljnyj marketyngh [Territorial marketing]. SPb.: Pyter, 368 [in Ukrainian].

14. Pankrukhyn A.P. Marketyngh terrytoryj [Marketing of territories]. marketologi.ru. Retrieved from http:// www.marketologi.ru/books/mterr.html [in Ukrainian]. 
15. Nacionaljnyj bank Ukrajiny. Zalyshky za instrumentamy prjamykh investycij za reghionamy, krajinamy svitu ta vydamy ekonomichnoji dijaljnosti [National Bank of Ukraine. Balances on direct investment instruments by regions, countries of the world and types of economic activity]. bank.gov.ua. Retrieved from https://bank.gov.ua/ua/statistic/sectorexternal/data-sector-external\#1 [in Ukrainian]. 